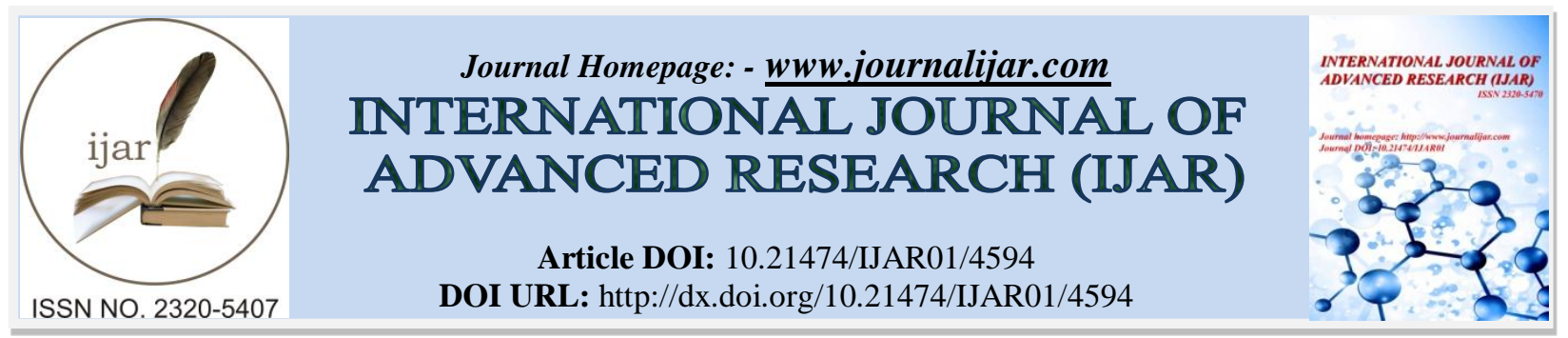

RESEARCH ARTICLE

\title{
A POTENTIAL SUSTAINABLE (STONE) TOURIST DESTINATION, BANDEBAMBLI.
}

\author{
Ar. Nishant Nathani ${ }^{1}$, Ar. Pragnya Prakash ${ }^{2}$ and Ar. Mustakeem R Khan ${ }^{3}$. \\ 1. Asst. Prof., Architecture \& Planning, Amity University Haryana, India. \\ 2. Asst. Director, Town Planning, Karnataka. \\ 3. Asst. Prof., Architecture \& Planning, Amity University Haryana, India.
}

\section{Manuscript Info}

Manuscript History

Received: 24 April 2017

Final Accepted: 26 May 2017

Published: June 2017

Key words:-

Sustainable village, tourist destination,

Stone construction, traditional

knowledge

\begin{abstract}
Indian village are by default sustainable because of their indigenous sustainable construction techniques and uses of building material. Sustainability in Indian settlements is a phenomenon which is shaped based on the living practices rather than an induced character to the built habitat. Bandebamli is one of such village in Karnataka which stands out due to its special architectural character. This paper will talk about the sustainable material and construction technologies used in the settlement. The basic material used for construction is visually appealing rustic stones available in plenty near to the village. The building is designed according to hot dry climate, prevailing that region. Social, economic, and artistic character of the settlement is evolved with a quality character. Explicit wooden joinery details in load bearing structure and exquisite wooden carvings symbolize the social and economic classes among the society are few unique features. Due to migration of people out of settlement for economic reasons, many of these unique houses are in stage of dilapidation and require urgent attention to save the rich traditional wisdom. There is a need to develop this settlement as a sustainable tourist destination.
\end{abstract}

Copy Right, IJAR, 2017,. All rights reserved.

\section{Introduction:-}

Sustainability in Indian villages is an inbuilt indigenous phenomenon. This paper focuses on one such vernacular settlement describing the traditional approach towards sustainability. The settlement is almost 600 years old and the buildings are 250-300 years old. The settlement - "Bandebambli", etymologically defined in "Kannada Language" as Bande - Rock, Bam - back, Bli - near, the village is situated at the back of the granite rock. Enunciating sustainability through Planning and Architectural practices shaped due to socio economic and environmental practices. This paper will point out the sustainable practices used by the village, which is worth to be developed a potential sustainable tourist destination.

\section{Location \& Demography:-}

The settlement is in Yadgir district, state of Karnataka in India. 38 Kilometers from the district headquarters and is connected by Other District Road (ODR) [1]. Latitude - $17^{\circ} 46^{\prime} 60 \mathrm{~N}$, Longitude - $76^{\circ} 45^{\prime}$ 0E, Altitude - 355 meters, Area: 1.8 sq. km. It has a population of 4000 as per 2001 census. Temperature in this region varies from 48 degree Celsius in summer to 13 degree Celsius in winters. The settlement lies at the bank of river Krishna and in between Krishna and Bhima rivers, the area is named as Sagara Nadu. 


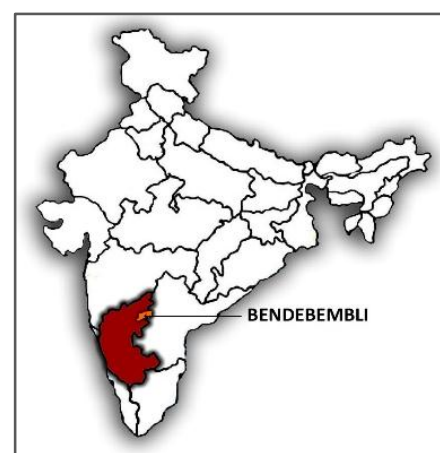

Fig 1:- Settlement Location

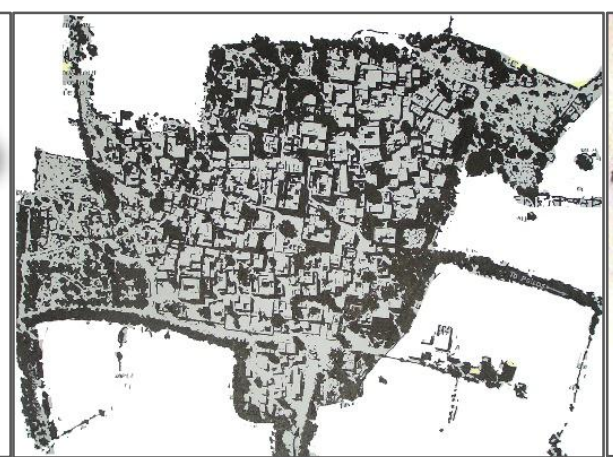

Fig 2:- Plan of village

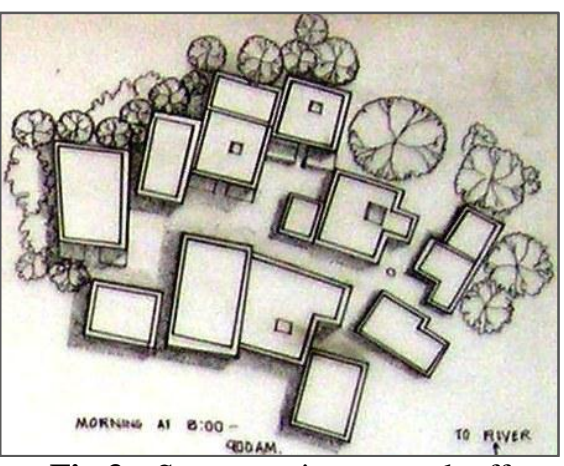

Fig 3:- Square acting as stack effect

\section{History - Evolution of Settlement:-}

History of settlement dates back to 14th century. The revolt of Muslim officers appointed from Delhi resulted in founding of Bahamani Sultanate by Hassan Gangu, who chose Gulbarga (approx. $125 \mathrm{~km}$ from settlement) as his capital. The Bahmani Sultanate chose Bandebambli as a refugee camp for their soldier's family, while the soldier is serving in war or in danger [2].

The presence of river and granite rock influence the location of the settlement. River serves for agrarian purpose, a similar practice of traditional settlements around world and granite rock serving as a defense for watching area to keep vigilant to far places. The granite rock also used as building material for construction of buildings. The bold, rustic and massive elevation made out white granite resembles the concept of forts having elements such as Overhangs, Chatries, Courtyards, highly decorative entrance doors add on to the aesthetics.

\section{Sustainable aspects of the village:- \\ Village Planning:-}

Village planning is per the basic principle of Hot Dry Climate. Where the village is having narrow streets measuring $1.5 \mathrm{~m}$ to $5 \mathrm{~m}$ wide. Low height buildings in narrower streets while building height increases with increase in street width, to shadow the streets on sunny days.

\section{Village square:-}

Village is planned in such a way that there are squares at designed among few houses. Squares of village used for stack effect to drag air: The shaded streets would lead to squares. The squares paved by stones heats up air, hot air goes up, to fill that gap the air comes from the shadowed streets. Squares are major component of the settlement fabric with multiple functions as social gatherings, agriculture produce processing with larger courtyards being used for festival gatherings and entertainment purposes.

\section{Sustainable Construction Material:-}

White granite stone is the main building material used for construction. It is sustainable because found within 50 $\mathrm{KM}$ radius. Quarrying process is manually done. Animal driven vehicle is used for taking material to the site instead of biofuel. Masons and artisans are locally available. 


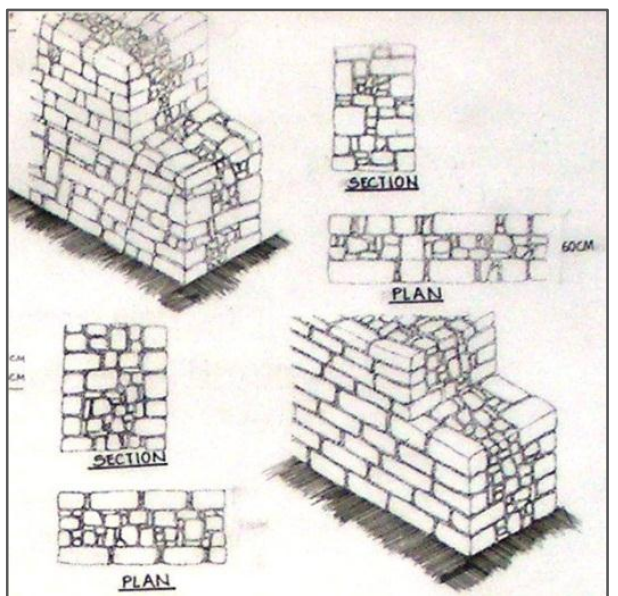

Fig 4:- Stone wall construction

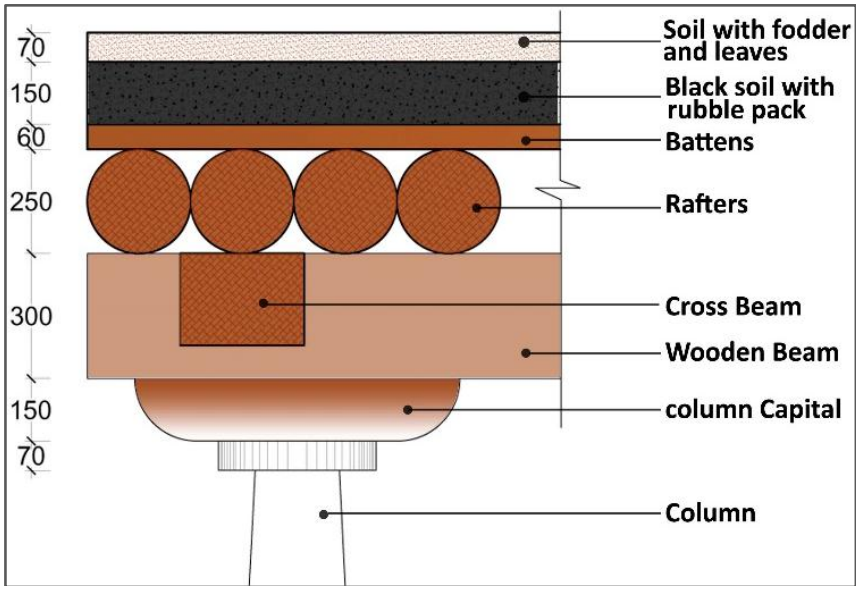

Fig 5:- Sustainable roof construction (Dimensions in MM)

\section{Sustainable wall construction:-}

The walls are made up of stone having thickness between 600-800 MM throughout the settlement irrespective of internal or external wall. Lime and clay is being used as binding mortar instead of cement Mud and lime also helps to increase heat lag, therefore reducing transmission of heat due to convection. . Section of typical stone wall has been shown in fig-4

\section{Sustainable roof Construction:-}

The roof of the buildings is sustainable and is of great significance. The roof consists of 5 layers; starting with wooden beam, second layer is rafter, third is batten, fourth is Black Soil with rubble pack and top layer is clay, leaves and straw. The thickness of the roof increased in longer term as the new layer of mud applied on the top layer before rainy season. Section of typical roof has been shown in fig-5

\section{Fenestration:-}

In the hot dry climate, it is desired that the fenestration should be minimal to avoid air change and stop sun to enter the house. Such kind of minimal fenestration is seen throughout the village. This artistic fenestration became one of the characteristic of village.

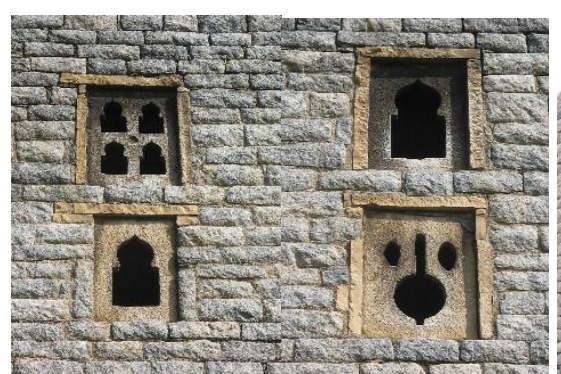

Fig 6:- Types of fenestration
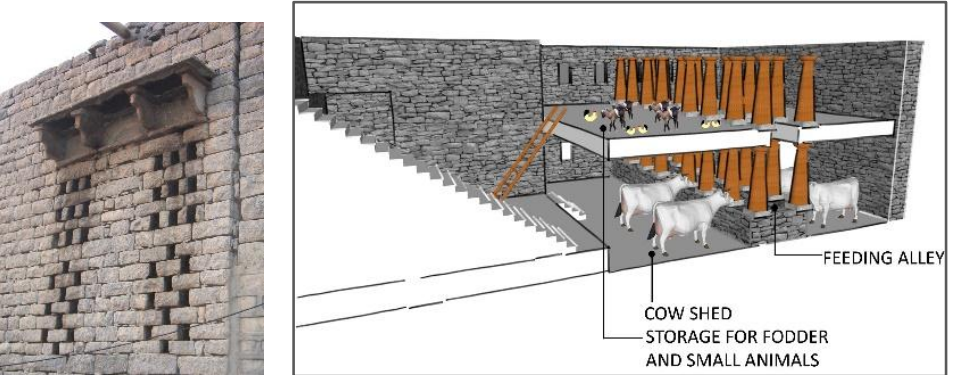

Fig 7:- Split level for animal habitat

\section{Split floor level for Animals:-}

Animals are integral part of the villagers. To protect animals from the heat and sun, animals living spaces has also been designed in the house. To optimize the space utilization, animals have been placed in split floor level. In higher income group houses, cow shed was segregated from living area but in lower income group cow shed is the part of living area as shown in figure -7

\section{Water supply techniques from well to interior:-}

The caste and class system is still prevailed in the village. Because of this stigma, several unique techniques were evolved in architecture. The higher class employed workers of lower class who were not allowed inside house or certain part of house. The source of water to house is well in the backyard of the house. Workers were employed to 
fetch water from well and arrangements are made in the building features with channels connecting from backyard near well to kitchen and bathroom inside house, explains in figure -8

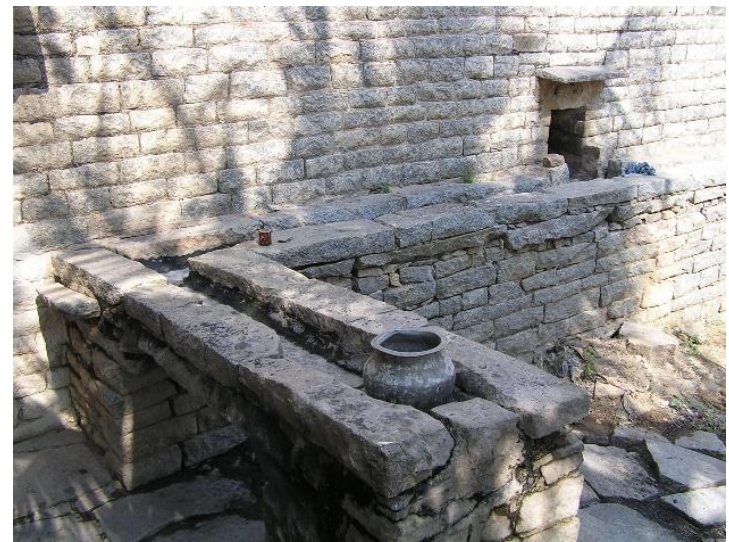

Fig 8:- Water supply system outside to inside

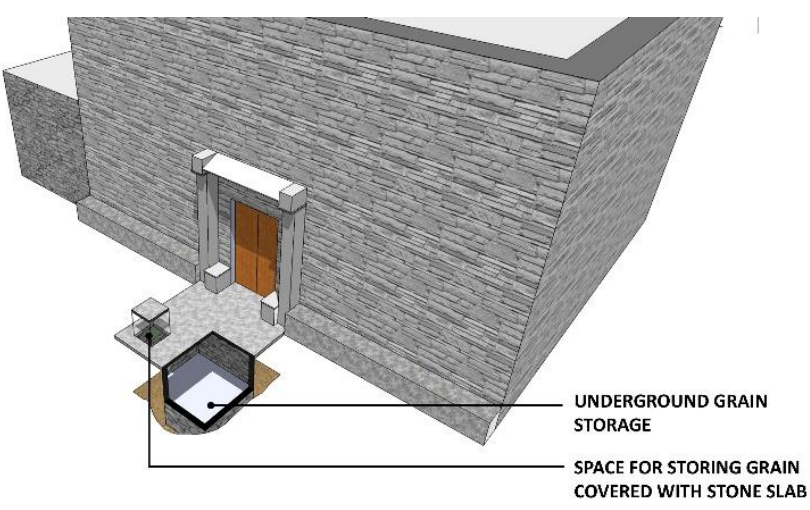

Fig 9:- Underground grain storage system

\section{Sustainable Grain Storage Technique: i) Under Staircase:-}

For the optimization of space utilization a staircase is being used for storage purposes. The part below steps is used to store grains. Maize is dropped from the top landing of the staircase. For daily use, a small opening is kept at the first riser from the ground level to pull out required maize. ii) Underground Storage: Storage chambers were made underground in the courtyards or sometimes outside the house in the lane. The inner surfaces of the chambers were treated with soil, kerosene oil and cow dung and chaff. The maize was stored and the surface is made as before for regular usage, open for traffic, as shown in Fig-9

\section{Sustainable Toilets:-}

Fig-10 explains that the community toilets were present since the inception of the settlement. The toilets were raised stone slabs about 1 meter above ground and enclosed platform with slit slabs as toilet seat. The excreta slip through the slit onto the ground or pit where it is manually cleaned later or animals cleared the waste.

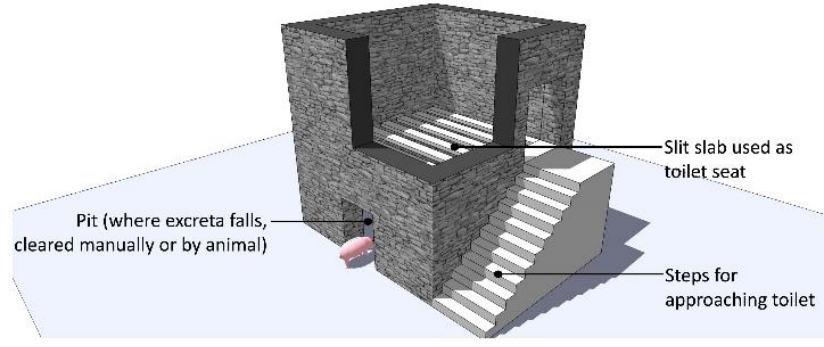

Fig 10:- Community toilet detail

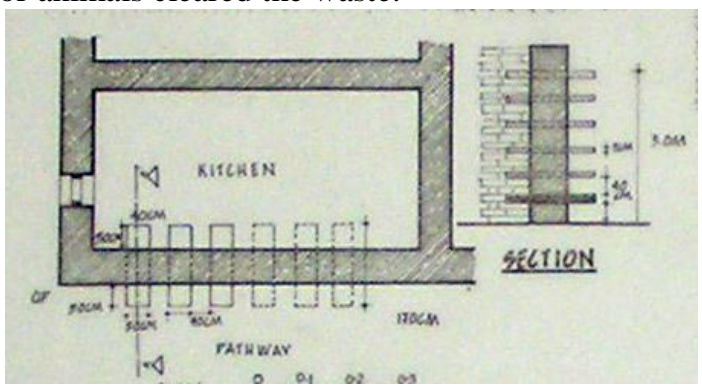

Fig 11:- Plan \& Section of steps and racks

Steps Used as Storage Racks A stone slab is fixed in wall in such a way that half of the portion towards exterior of the house is used as staircase and another half which is inside the house is used as a shelf in kitchen. These slabs are jammed at centre by stone wall as shown is fig- 11 .

Jharokha (Balconies) The concept of Jharokha was adopted from Rajasthan. Jharokha were projecting and were supported by cantilever stone slabs. These cantilever stone slabs were carved to resemble the "neck of the horse" and visually pleasing. Interior of the balconies was of compactly arranged stone chips and plastered from Exterior. As in figure 12 


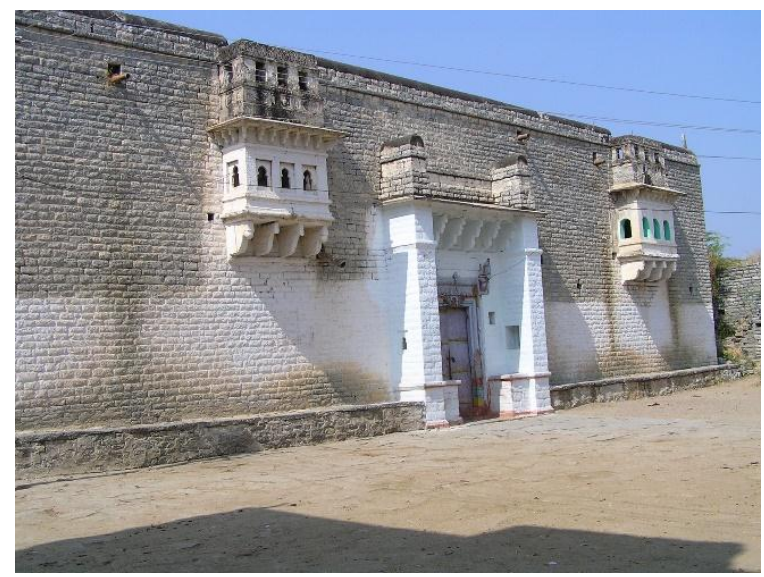

Fig 12:- Location of Jharokha (balcony) in a house

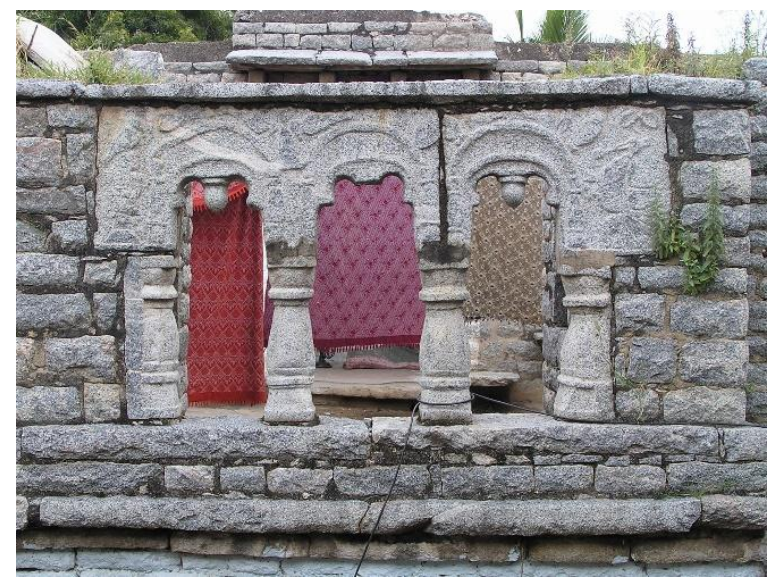

Fig 13:- Stone Chiseling Work

\section{Stone Chiseling:-}

The villagers possess technique of obtaining granite from the rock without heavy tools. The stones are removed in layers for use. Required part of the rock is identified and fire is burnt on top of it continuously for a day or two. Due to the heat, the rock becomes brittle. It is chiseled off with minimum tool and dressed (surface preparation) as per the need. Through this technique the whole settlement is built.

\section{Conclusion:-}

Bandebambli has a potential to develop as a sustainable tourist destination. As the village is practicing all indigenous the sustainable technique such as use of locally available material, construction practices, farming etc. any of the practices in the village is not polluting the environment.

\section{References:-}

1. Gazette of India - Gulbarga

2. National Association of Students of Architecture documentation, 2005- PDA college of engineering, Gulbarga, Karnataka, India.

3. Vastu Shastra Readings- Dr. A . Achiyutan

4. Dictionary of Architecture- Dr. Henry Parker

5. Indian Canvas Re- rendered - NIDC cell, NASA, 2004

6. Khan M R, Prakash P \& Nathani N, Sustainable Indian Architecture, "Case Study - Bandebambli", Journal of Basic and Applied Engineering Research, 2015, volume -2, issue - 8, http://www.krishisanskriti.org/ijbad1.php?Id=225 